\title{
PENGARUH BOBOT KOLONI DAN JENIS PAKAN TERHADAP KUALITAS PUPUK ORGANIK CAIR KOMPOS CACING Lumbricus rubellus \\ (The Effect Of Colony Weight and Feed Type on The Quality Of Liquid Organic Fertilizer Vermicompost Lumbricus rubellus)
}

\author{
Jaya, A., ${ }^{1 *)}$ Mulahartani, R. ${ }^{1)}$, Kamilah ${ }^{1)}$ dan Lautt, B.S. ${ }^{1)}$ \\ ${ }^{1)}$ Prodi Agroteknologi, Jurusan Budidaya Pertanian Fakultas Pertanian Universitas Palangka Raya \\ Telpon / HP. $081256445858 \quad{ }^{*}$ Corresponding author: adijaya@agr.upr.ac.id
}

Disetujui : $21 / 8 / 2018 \quad$ Disetujui : $5 / 9 / 2018$

\begin{abstract}
Liquid organic fertilizer is able to provide nutrients from leachate extract (liquid) as a result of changes in worm metabolism, growing media or residual worm feed as a result of the composting process. This study aims to determine the interaction between feed type with worm colony weight as well as the influence of worm weight and type of feed on the quality of L. rubellus compost liquid organic fertilizer. The research was carried out at the experimental field of the Department of Agriculture and in the analytical laboratory of the University of Palangka Raya using completely randomized design (CRD) with $3 \times 3$ factorial pattern. The first factor was colony weights of $L$. rubellus $(\mathrm{C} 1: 50 \mathrm{~g}, \mathrm{C} 2: 75 \mathrm{~g}$ and $\mathrm{C} 3: 100 \mathrm{~g})$ and the second was types of feed (P0 : control, $\mathrm{P} 1$ : green vegetable waste and P2: sedge-grass leaves). The results showed that $100 \mathrm{~g}$ worm colony weights with feed from alang-alang leaves produced the highest Nitrogen nutrient (18.33 $\left.\mathrm{mg} \mathrm{g}^{-1}\right)$, on phosphorus nutrients the interaction was not significant but had a significant effect from the treatment of feed where the green vegetable waste produced the lowest phosphorus nutrients $\left(85.67 \mathrm{mg} \mathrm{g}^{-1}\right)$, but the treatment without feed (control) and sedge-grass leaves (Imperata cylindica) and the treatment of worm colony weight were not affect on the quality of $L$. rubellus compost liquid organic fertilizer.
\end{abstract}

Keywords : Colony Weight, Feed Type, Liquid Organic Fertilizer, Lumbricus rubellus

\begin{abstract}
ABSTRAK
Pupuk organik cair yang mampu menyediakan unsur hara dapat dibuat dari ekstrak lindi (cairan) hasil perombakan metabolisme cacing, media tumbuh atau sisa pakan cacing melalui proses pengomposan. Penelitian ini bertujuan mengetahui interaksi jenis pakan dan bobot koloni cacing, serta pengaruh bobot koloni dan pengaruh jenis pakan terhadap kualitas pupuk organik cair kompos cacing L. rubellus. Penelitian dilaksanakan di kebun percobaan Jurusan Budidaya Pertanian dan laboratorium analitik Universitas Palangka Raya menggunakan rancangan acak lengkap (RAL) pola faktorial $3 \times 3$. Faktor pertama yakni 3 bobot koloni cacing L. rubellus $(\mathrm{C} 1: 50 \mathrm{~g}, \mathrm{C} 2: 75 \mathrm{~g}$ dan C3 : $100 \mathrm{~g}$ ). Faktor kedua yakni 3 jenis pakan (P0 : kontrol, P1 : limbah sayur hijau dan P2 : daun alang-alang). Hasil penelitian menunjukkan bahwa interaksi bobot koloni cacing $100 \mathrm{~g}$ dengan pakan daun alang-alang menghasilkan kandungan nitrogen kompos paling tinggi (18,33 mg $\left.\mathrm{g}^{-1}\right)$. Kandungan fosfor tidak dipengaruhi oleh interaksi perlakuan. Perlakuan tunggal pakan limbah sayur nyata menghasilkan fosfor paling rendah $\left(85,67 \mathrm{mg} \mathrm{g}^{-1}\right)$. Perlakuan tanpa pakan dan pakan daun alang-alang tidak memberikan hasil yang berbeda terhadap kandungan fosfor. Perlakuan bobot koloni cacing tidak berpengaruh nyata terhadap kualitas pupuk organik cair kompos cacing.
\end{abstract}

Kata Kunci : Bobot Koloni, Jenis Pakan, Pupuk Organik Cair, Lumbricus rubellus 


\section{PENDAHULUAN}

Kendala utama yang dihadapi dalam budidaya tanaman di Kalimantan Tengah umumnya berkaitan dengan kondisi lahan yang berupa tanah marginal, baik gambut maupun tanah padat. Salah satu syarat yang diperlukan adalah tersedianya media tumbuh yang baik, yang sesuai bagi pertumbuhan tanaman tersebut. Oleh karena itu untuk mengatasi kendala kesuburan pada lahan marginal, terutama untuk memperbaiki sifat fisika, kimia dan biologis tanah, maka pemberian pupuk organik menjadi sangat penting dilakukan. Pupuk organik selain berperan memperbaiki struktur tanah, juga mampu menyediakan unsur hara yang diperlukan tanaman, terutama sebagai sumber N, P dan K (Lingga dan Marsono, 2000).

Pupuk organik merupakan salah satu pupuk berbahan alami yang tidak meninggalkan residu pada hasil tanaman, sehingga aman bagi kesehatan manusia (Musnamar, 2007). Pupuk organik cair merupakan pupuk berbentuk cairan, umumnya hasil ekstrak bahan organik yang telah dilarutkan dengan pelarut seperti air, alkohol atau minyak. Pupuk organik cair lebih mudah diserap oleh tanaman dengan penyemprotan, terutama melalui daun, karena unsur-unsur di dalamnya sudah terurai, sehingga dapat disebut sebagai pupuk daun. Selain itu dapat juga diaplikasikan di sekitar tanaman (Djuarnani dkk., 2005).

Pupuk organik cair salah satunya dihasilkan dari proses pengomposan cacing. Jenis cacing tanah yang biasa digunakan dalam pembuatan kompos adalah $L$. rubellus. Cacing ini sering ditemukan di bawah timbunan dedaunan atau kotoran ternak dan sering hidup di lapisan yang mendekati permukaan tanah. Pupuk organik cair yang dihasilkan berupa ekstrak lindi (cairan) hasil perombakan metabolisme cacing, media tumbuh atau sisa pakan cacing hasil dari proses pengomposan (Djuarnani dkk., 2005). Lindi tersebut mengandung unsur hara, baik mikro maupun makro yang berguna bagi pertumbuhan tanaman, karena pemberian pupuk organik cair cacing ini dapat meningkatkan konsentrasi serapan nitrogen dan kalium oleh tanaman, sehingga pupuk cair cacing tersebut dijadikan sumber nitrogen dan kalium yang potensial untuk tanaman (Mulat, 2003).

Penggunaan cacing tanah dalam perombakan kotoran ternak dan sisa-sisa sayuran menjadi salah satu upaya menambah nilai guna limbah yang ada. Cacing tanah membutuhkan limbah berupa kotoran ternak maupun sisa sayuran sebagai media berkembang biak dan juga sebagai pakan (Sinha, 2009). Menurut Pangkulun (2010), cacing tanah merupakan salah satu organisme pengurai. Penguraian oleh cacing tanah lebih cepat dibanding mikrobia. Kemampuan cacing tanah mengurai bahan organik 3-5 kali lebih cepat. Cacing L. rubellus mampu mendegradasi senyawa lignoselulosa, dimana senyawa ini merupakan komponen utama tanaman yang menggambarkan jumlah sumber bahan organik yang dapat diperbaharui yang terdiri dari selulosa, hemiselulosa, lignin dan beberapa bahan ekstraktif lain (Pathma dan Sakthivel, 2012).

Hasil dari pencernaan cacing yang berupa kotoran akan menjadi tambahan makanan bagi bakteri pengompos (Sathianarayanan dan Khan, 2008). Penambahan bahan organik dengan cacing tanah dalam pembuatan pupuk kompos dapat mempersingkat waktu memproduksi pupuk kompos, hanya diperlukan separuh waktu dari pembuatan pupuk kompos konvensional (Munroe, 2003).

Pertumbuhan cacing tanah sangat bergantung pada jenis pakannya, pertumbuhan cacing tanah akan meningkat bila pakannya banyak mengandung bahan organik (Suin, 1997). Distribusi bahan organik dalam tanah berpengaruh terhadap cacing tanah, karena terkait dengan sumber nutrisinya, sehingga pada tanah miskin bahan organik hanya sedikit jumlah cacing tanah yang dijumpai. Pangkulun (1999) juga menyatakan, bahwa bobot cacing tanah sangat dipengaruhi oleh kondisi media dan ketersediaan nutrisi. Semakin berkurangnya ketersediaan nutrisi dalam media, akan menyebabkan aktivitas metabolisme menurun sehingga terjadi penurunan energi hasil metabolisme (Wulandari, 2000). 
Pakan yang diberikan kepada cacing akan menentukan jumlah dan kualitas pupuk yang dihasilkan (Setiadji dan Hartati, 2012). Secara umum limbah organik yang dapat dijadikan bahan pakan cacing yakni limbah sayuran, serbuk gergaji sisa media jamur, limbah hijauan, kotoran ternak, pelepah, daun, batang dan bongkol pisang, limbah jerami padi dan ampas tahu (Rozaq dan Novianto, 2010 )..

\section{BAHAN DAN METODE}

Penelitian dilakukan di kebun percobaan Jurusan Budidaya Pertanian dan laboratorium analitik Universitas Palangka Raya. Penelitian ini menggunakan rancangan acak lengkap (RAL) pola faktorial $3 \times 3$. Faktor perlakuan pertama yaitu 3 bobot koloni cacing L. rubellus $(\mathrm{C} 1: 50$ gram, $\mathrm{C} 2: 75$ gram dan C3 : 100 gram). Faktor perlakuan kedua yaitu 3 jenis pakan cacing (P0 : tanpa pakan/kontrol, P1 : limbah sayur hijau dan P2 : daun alang-alang/Imperata cylindrica).

Tempat penyimpanan kompos berupa rumah pengomposan $10 \mathrm{x} 4 \mathrm{~m}^{2}$ yang bertujuan untuk melindungi proses pengomposan dari gangguan hewan atau hama dan sinar matahari langsung. Rumah pengomposan menggunakan atap seng yang dilapisi atap daun pada lapisan bagian bawahnya dan dinding terbuat dari kain jala sehingga kondisi suhu tetap sejuk. Baskom pengomposan diletakkan pada lantai dengan ketinggian $1 \mathrm{~m}$ dari permukaan tanah.

Media tumbuh cacing dibuat dari $30 \mathrm{~kg}$ kotoran sapi yang ditambahkan air dengan perbandingan kotoran sapi dan air adalah 2 : 1 , kemudian diaduk merata dan didiamkan selama satu minggu untuk melunakkan media. Media harus lembab, namun tidak terlalu basah atau kering. Pakan cacing sesuai perlakuan berupa limbah sayur hijau, serta alang-alang yang diambil hanya bagian daunnya saja. Masing-masing bahan tersebut direndam dalam air selama 3 hari dengan perbandingan bahan pakan dan air adalah 1 : 2. Air rendaman diganti setiap hari. Setelah selesai perendaman, bahan pakan tersebut ditiriskan dari airnya dan siap digunakan.
Dua buah baskom plastik berukuran $26 \mathrm{~cm} \mathrm{x}$ $19 \mathrm{~cm} \times 9 \mathrm{~cm}$ disusun dengan cara baskom pertama di bagian bawah untuk menampung air cacing dan baskom kedua di bagian bagian atas untuk tempat media cacing. Dasar baskom atas dilubangi pada bagian bawahnya agar pupuk cair cacing dari baskom atas dapat menetes ke baskom bawah. Permukaan baskom atas dilapisi dengan kain kasa agar cacing tidak turun ke baskom bawah. Media tumbuh cacing dengan ketebalan $5 \mathrm{~cm}$ diletakkan di atas kain kasa. Potongan batang bambu diletakkan dalam baskom bawah pada masing-masing sisi baskom untuk menyangga baskom atas. Bibit cacing L. rubellus yang dipilih yang berumur muda (kecil) sebanyak $50 \mathrm{~g}, 75 \mathrm{~g}$ dan $100 \mathrm{~g}$, diletakkan di atas media masing-masing perlakuan yang sudah ditentukan, kemudian diamati hingga semua cacing masuk ke dalam media.

Baskom ditutup dengan terpal lalu diikat dengan tali, disimpan dalam rumah kompos agar tetap sejuk, tidak terkena sinar matahari, serta dioleskan lem tikus di sekeliling dinding luar baskom agar aman dari semut, tikus dan hama lain. Pemeliharaan media dilakukan dengan cara penggemburan media agar terjadi aerasi dalam media dan penyiraman media (untuk menjaga kelembabannya) dengan air sebanyak $250 \mathrm{ml}$ setiap 7 hari sekali. Air disiram secara merata di seluruh permukaan media. Pemberian pakan cacing dilakukan setiap 7 hari sekali. Pakan yang diberikan yaitu pakan yang telah dipotong kecil-kecil pasca perendaman dalam air, kemudian pakan ditebarkan secara merata di atas media.

Panen pupuk organik cair dilakukan setelah proses pengomposan berumur 35 hari. Panen dilakukan dengan cara mengambil cairan yang ditampung pada baskom bawah pengomposan. Pupuk organik cair yang dihasilkan tersebut diambil sampelnya kemudian di analisis $\mathrm{N}, \mathrm{P}, \mathrm{K}, \mathrm{pH}$ dan suhunya di laboratorium.

Variabel yang diamati meliputi :

1. Kandungan unsur hara makro pupuk organik cair yaitu N, P dan K. N total merupakan gabungan dari pengukuran $\mathrm{NH}_{3}$ (metode titrasi), $\mathrm{NO}_{2}$ dan $\mathrm{NO}_{3}$ (spektrofotometer), fosfor total (spektrofotometer) dan kalium (AAS). 
2. Derajat keasaman $(\mathrm{pH})$ pupuk organik cair diukur menggunakan $\mathrm{pH}$-meter.

3. Suhu pupuk organik cair diukur menggunakan thermometer.

4. Bobot akhir koloni cacing diukur dengan cara pada akhir penelitian cacing dipisahkan dari media kemudian ditimbang.

Data yang diperoleh dianalisis dengan analisis ragam (Anova) menggunakan uji $\mathrm{F}$ dengan taraf $\alpha=5 \%$. Apabila perlakuan berpengaruh nyata, dilanjutkan dengan uji beda nyata jujur (BNJ) pada taraf $\alpha=5 \%$ untuk mengetahui perbedaan antara perlakuan.

\section{HASIL DAN PEMBAHASAN}

\section{Kandungan Unsur Hara Makro}

Kandungan unsur hara $\mathrm{N}$ pada pupuk organik cair kompos cacing L. rubellus nyata dipengaruhi interaksi bobot koloni cacing dengan jenis pakan. Unsur hara P dipengaruhi dengan nyata hanya oleh perlakuan jenis pakan, sedangkan kandungan kalium tidak dipengaruhi oleh kedua perlakuan (Tabel 1-3, serta Gambar 1-3).

Tabel 1. Kandungan $\mathrm{N}$ pupuk organik cair kompos cacing Lumbricus rubellus $\left(\mathrm{mg}^{1^{-1}}\right)$

\begin{tabular}{ccccr}
\hline \multirow{2}{*}{$\begin{array}{c}\text { Bobot Koloni } \\
\text { Cacing (C) }\end{array}$} & \multicolumn{3}{c}{ Jenis Pakan (P) } & \multirow{2}{*}{ Rata-rata } \\
\cline { 2 - 4 } & Tanpa Pakan & $\begin{array}{c}\text { Limbah Sayur } \\
\text { Hijau }\end{array}$ & $\begin{array}{c}\text { Daun } \\
\text { Alang-alang }\end{array}$ & \\
\hline $50 \mathrm{~g}$ & $15,06^{\mathrm{bc}}$ & $9,62^{\mathrm{ab}}$ & $11,06^{\mathrm{abc}}$ & 11,91 \\
$75 \mathrm{~g}$ & $10,12^{\mathrm{ab}}$ & $8,03^{\mathrm{ab}}$ & $10,35^{\mathrm{ab}}$ & 9,05 \\
$100 \mathrm{~g}$ & $9,59^{\mathrm{ab}}$ & $6,74^{\mathrm{a}}$ & $18,33^{\mathrm{c}}$ & 11,55 \\
\hline Rata-rata & $11,59^{\mathrm{b}}$ & $8,13^{\mathrm{a}}$ & $13,25^{\mathrm{b}}$ & \\
\hline
\end{tabular}

Keterangan: Angka-angka pada baris dan kolom yang sama, yang diikuti oleh huruf yang menunjukkan tidak berbeda nyata menurut uji BNJ pada taraf $5 \%$.

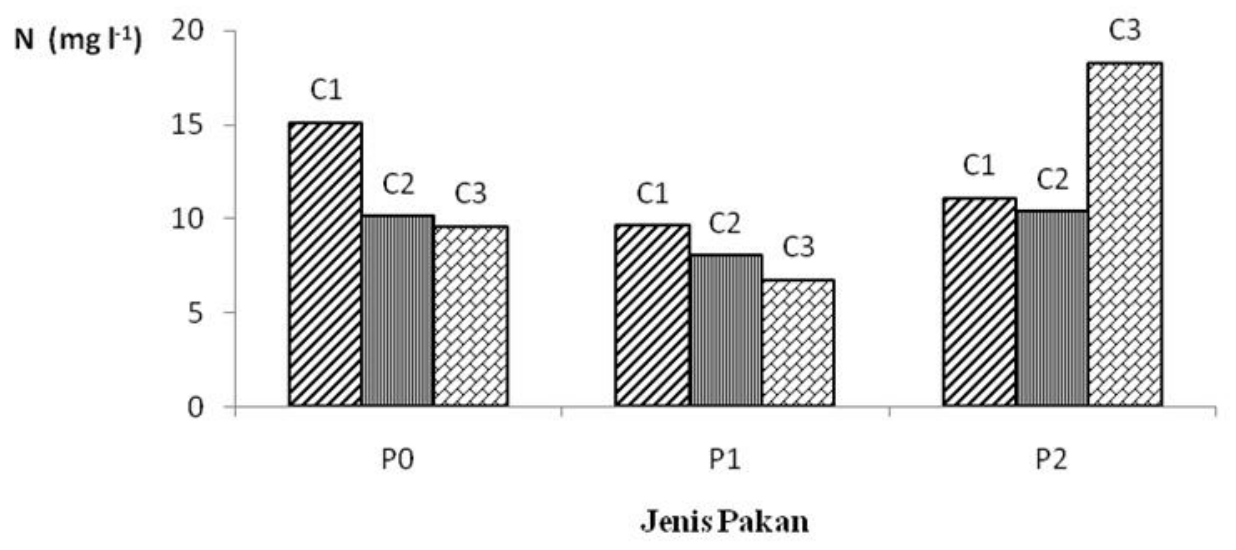

Jenis pakan : P1 = kontrol, $\mathrm{P} 2=$ limbah sayur hijau, $\mathrm{P} 3=$ daun alang-alang Bobot koloni : $\mathrm{C} 1=50 \mathrm{~g}, \mathrm{C} 2=100 \mathrm{~g}, \mathrm{C} 3=150 \mathrm{~g}$

Gambar 1. Pengaruh interaksi jenis pakan dengan bobot koloni cacing terhadap kandungan nitrogen pupuk organik cair $(\mathrm{P}<0,05)$ 
Tabel 1 dan Gambar 1 menunjukkan kombinasi antara bobot koloni cacing $100 \mathrm{~g}$ dengan jenis pakan alang-alang menghasilkan kandungan $\mathrm{N}$ tertinggi yaitu $18,33 \mathrm{mg} \mathrm{l}^{-1}$. Hal ini diduga karena semakin tinggi bobot koloni cacing $L$. rubellus maka semakin cepat terdekomposisi bahan organik dalam media, sehingga semakin meningkatkan unsur hara yang tersedia. Potensi sumber unsur hara tersebut tergantung dari bahan-bahan organik yang dikomposkan. Dalam hal ini alangalang mengandung unsur hara yang dapat digunakan sebagai pemacu pertumbuhan. Daun alang-alang mengandung senyawa N, P, $\mathrm{K}, \mathrm{Ca}, \mathrm{Mg}$, dan $\mathrm{Si}$, sedangkan pada bagian rhizom mengandung senyawa $\mathrm{Fe}, \mathrm{Mn}, \mathrm{Z}$ dan $\mathrm{Cu}$ (Soepardi, 1980). Sugiharto (2006) menyatakan, bahwa jumlah cacing tanah terbanyak dan waktu pengomposan terlama menghasilkan kandungan NPK tertinggi. Dalam hal ini cacing tanah berpengaruh mempercepat waktu pengomposan.

Tabel 2 dan Gambar 2 menunjukkan jenis pakan limbah sayur menghasilkan kandungan unsur hara $\mathrm{P}$ yang paling rendah, sedangkan cacing tanpa pakan dan yang diberi pakan alang-alang tidak berbeda nyata kandungan fosfornya. Pakan limbah sayur menghasilkan unsur hara fosfor yang rendah. Hal ini diduga akibat perlakuan perendaman limbah sayuran hijau, serta kandungan P pada bahan yang memang rendah.

Menurut Agustina (2013), bahan organik yang mengandung fosfor yang tinggi terdapat pada limbah kubis. Kerjasama cacing tanah dengan Mikroorganisme telah membuat proses penguraian berjalan dengan baik. Walaupun sebagian besar proses penguraian dilakukan oleh mikroorganisme, namun terlebih dahulu bahan organik didegradasi oleh cacing, sehingga kerja mikroorganisme menjadi lebih cepat dan efektif (Husain dkk., 2004).

Pada Tabel 3 semua perlakuan tidak berpengaruh nyata terhadap unsur $\mathrm{K}$ dalam kompos. Hal ini menunjukkan kandungan unsur hara kalium dalam pupuk organik cair tidak dipengaruhi oleh bobot koloni cacing dan jenis pakan yang diberikan.

Tabel 2. Kandungan P pupuk organik cair kompos cacing Lumbricus rubellus $\left(\mathrm{mg} \mathrm{l}^{-1}\right)$

\begin{tabular}{ccccc}
\hline \multirow{2}{*}{$\begin{array}{c}\text { Bobot Koloni } \\
\text { Cacing }(\mathrm{C})\end{array}$} & \multicolumn{3}{c}{ Jenis Pakan (P) } & Rata-rata \\
\cline { 2 - 4 } & Tanpa Pakan & $\begin{array}{c}\text { Limbah } \\
\text { Sayur Hijau }\end{array}$ & $\begin{array}{c}\text { Daun } \\
\text { Alang-alang }\end{array}$ & \\
\hline $50 \mathrm{~g}$ & 82,33 & 64,67 & 78,33 & 75,11 \\
$75 \mathrm{~g}$ & 80,67 & 56,33 & 91,67 & 76,22 \\
$100 \mathrm{~g}$ & 89,67 & 58,67 & 87,00 & 78,44 \\
\hline Rata-rata & $84,22^{\mathrm{b}}$ & $59,89^{\mathrm{a}}$ & $85,67^{\mathrm{b}}$ & \\
\hline
\end{tabular}

Keterangan : Angka-angka pada baris yang sama yang diikuti oleh huruf yang berbeda menunjukkan berbeda nyata menurut uji BNJ pada taraf $5 \%$.

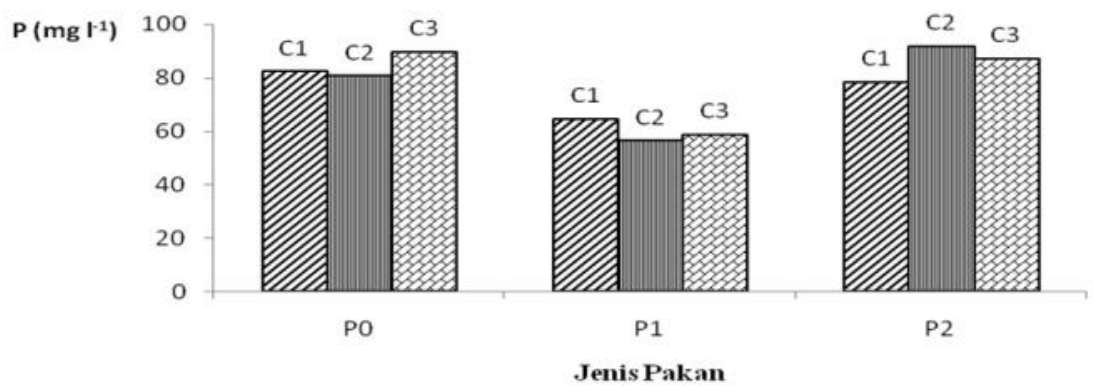

Jenis pakan : $\mathrm{P} 1=$ kontrol, $\mathrm{P} 2=$ limbah sayur hijau, $\mathrm{P} 3=$ daun alang-alang Bobot koloni : $\mathrm{C} 1=50 \mathrm{~g}, \mathrm{C} 2=100 \mathrm{~g}, \mathrm{C} 3=150 \mathrm{~g}$

Gambar 2. Pengaruh jenis pakan terhadap kandungan fosfor pupuk organik cair $(\mathrm{P}<0,05)$ 
Tabel 3.Kandungan K pupuk organik cair kompos cacing Lumbricus rubellus $\left(\mathrm{mg} \mathrm{l}^{-1}\right)$

\begin{tabular}{ccccc}
\hline \multirow{2}{*}{$\begin{array}{c}\text { Bobot Koloni } \\
\text { Cacing }(\mathrm{C})\end{array}$} & \multicolumn{3}{c}{ Jenis Pakan (P) } & \\
\cline { 2 - 4 } & $\begin{array}{c}\text { Tanpa } \\
\text { Pakan }\end{array}$ & $\begin{array}{c}\text { Limbah Sayur } \\
\text { Hijau }\end{array}$ & $\begin{array}{c}\text { Daun } \\
\text { Alang-alang }\end{array}$ & \\
\hline $50 \mathrm{~g}$ & $3.036,10$ & $3.290,82$ & $3.295,25$ & $3.163,46$ \\
$75 \mathrm{~g}$ & $3.006,03$ & $2.772,62$ & $3.241,70$ & $2.889,33$ \\
$100 \mathrm{~g}$ & $3.527,34$ & $2.873,49$ & $3.553,83$ & $3.200,41$ \\
\hline Rata-rata & $3.189,83$ & $2.978,98$ & $3.363,59$ & \\
\hline
\end{tabular}

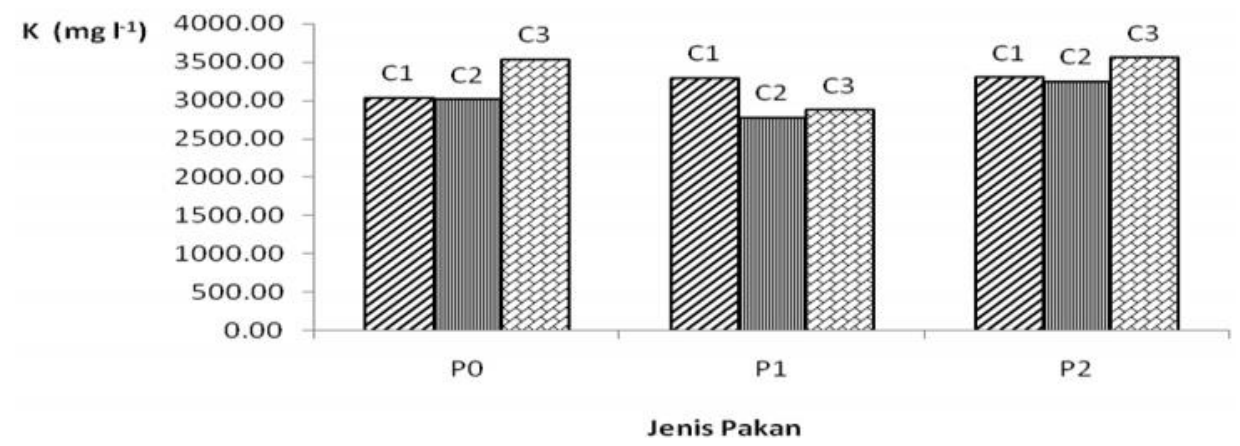

Jenis pakan : $\mathrm{P} 1=$ kontrol, $\mathrm{P} 2=$ limbah sayur hijau, $\mathrm{P} 3=$ daun alang-alang Bobot koloni : $\mathrm{C} 1=50 \mathrm{~g}, \mathrm{C} 2=100 \mathrm{~g}, \mathrm{C} 3=150 \mathrm{~g}$

Gambar 3. Pengaruh jenis pakan terhadap kandungan kalium pupuk organik cair $(P>0,05)$

\section{Bobot Akhir Koloni Cacing Lumbricus rubellus}

Hasil analisis ragam terhadap parameter bobot akhir koloni cacing menunjukkan bahwa bobot awal koloni cacing serta jenis pakan memberikan pengaruh yang nyata. Setelah diuji lanjut dengan uji Beda Nyata Jujur (BNJ) pada taraf $5 \%$ diperoleh hasil yang disajikan pada Tabel 4 .

Tabel 4 menunjukkan bahwa pakan limbah sayuran hijau menghasilkan bobot koloni akhir cacing paling berat dibandingkan dengan daun alang-alang dan tanpa pakan. Bobot koloni cacing tanpa pakan mengalami penurunan, diduga kandungan nutrisi pada media tumbuh tidak mencukupi untuk pertumbuhan cacing sehingga menyebabkan cacing menjadi kurus ataupun mati. Jenis pakan sayuran hijau menghasilkan bobot akhir koloni terberat karena pakan sayuran hijau mengandung protein yang cukup baik untuk pertumbuhannya cacing. Hal ini ditunjukkan dengan meningkatnya bobot cacing pertumbuhannya cacing. Hal ini ditunjukkan dengan meningkatnya bobot cacing.

Bobot cacing Lumbricus rubellus sangat dipengaruhi oleh kondisi media dan ketersediaan nutrisi (Pangkulun, 1999). Bahan yang mengandung protein sangat penting dalam menentukan penyebaran dan produksi cacing. Cacing dapat meningkat berat badannya pada media yang berprotein tinggi (Abbot dan Parker, 1981). Limbah sayuran mempunyai kandungan gizi rendah bila dilihat dari kandungan serat kasar yang tinggi dengan kandungan air yang tinggi pula, namun dalam basis kering kandungan protein kasar sayuran cukup tinggi, yaitu berkisar antara $15-24 \%$, sedangkan kandungan protein kasar alang-alang hanya 9,60\% (Saenab dan Retnani, 2011). Mikroorganisme akan mendegradasi bahan organik yang terdapat dalam bahan komposan, seperti kabohidrat, protein, lemak menjadi bentuk yang lebih sederhana, seperti glukosa, asam amino dan asam lemak. 
Tabel 4. Pengaruh jenis pakan dan bobot awal terhadap bobot akhir koloni cacing Lumbricus rubellus $(\mathrm{g})$

\begin{tabular}{ccccc}
\hline \multirow{2}{*}{$\begin{array}{c}\text { Bobot Koloni } \\
\text { Cacing }(\mathrm{C})\end{array}$} & \multicolumn{3}{c}{ Jenis Pakan (P) } & \multirow{2}{*}{ Rata-rata } \\
\cline { 2 - 4 } & Tanpa & $\begin{array}{c}\text { Limbah } \\
\text { Sayar Hijau }\end{array}$ & $\begin{array}{c}\text { Daun } \\
\text { Alang-alang }\end{array}$ & \\
\hline $50 \mathrm{~g}$ & 47,93 & 69,40 & 58,57 & $58,63^{\mathrm{a}}$ \\
$75 \mathrm{~g}$ & 70,57 & 89,13 & 80,40 & $80,03^{\mathrm{b}}$ \\
$100 \mathrm{~g}$ & 91,93 & 112,30 & 105,00 & $103,08^{\mathrm{c}}$ \\
\hline Rata-rata & $70,14^{\mathrm{a}}$ & $90,28^{\mathrm{c}}$ & $81,32^{\mathrm{b}}$ & \\
\hline
\end{tabular}

Keterangan : Angka-angka pada baris atau kolom yang sama, yang diikuti oleh huruf yang berbeda menunjukkan berbeda nyata menurut uji BNJ pada taraf 5 $\%$.

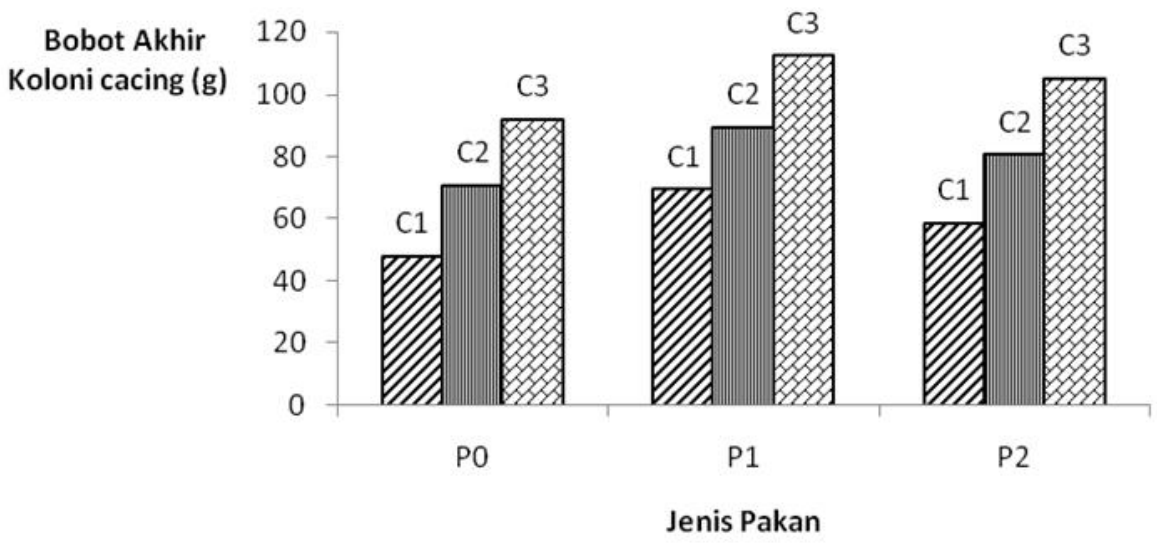

Jenis pakan : P1 = kontrol, P2 = limbah sayur hijau, P3 = daun alang-alang Bobot koloni : $\mathrm{C} 1=50 \mathrm{~g}, \mathrm{C} 2=100 \mathrm{~g}, \mathrm{C} 3=150 \mathrm{~g}$

Gambar 4. Pengaruh masing-masing faktor tunggal jenis pakan dan bobot awal koloni terhadap bobot akhir koloni cacing Lumbricus rubellus $(\mathrm{P}<0,05)$

Bahan organik dalam bentuk sederhana ini dapat dengan mudah dicerna atau diserap cacing tanah, sehingga dapat dimanfaatkan secara efektif untuk pembentukan jaringan tubuh baru. Hal ini ditandai dengan adanya peningkatan bobot badan cacing tanah (Noviansyah dkk., 2015).

Derajat Keasaman (pH) Pupuk Organik Cair Kompos Cacing L. rubellus

Jenis pakan memberikan pengaruh nyata terhadap $\mathrm{pH}$ pupuk organik cair (Tabel 5). Jenis pakan dapat meningkatkan $\mathrm{pH}$ pupuk organik cair kompos cacing L. rubelllus, dimana pakan limbah sayuran menghasilkan $\mathrm{pH}$ tertinggi dibandingkan jenis pakan lalinnya. Perbedaan $\mathrm{pH}$ tersebut terjadi karena dalam suatu media pengomposan, $\mathrm{pH}$ awal merupakan salah satu faktor yang mempengaruhi aktivitas mikroorganisme pada saat proses pengomposan. Nilai $\mathrm{pH}$ menunjukkan banyaknya konsentrasi ion $\mathrm{H}^{+}$ dalam media pengomposan. Apabila kadar ion hidrogen tinggi, maka pupuk organik yang dihasilkan akan bersifat alkali/basa. Pada proses dekomposisi bahan organik terjadi aktivitas mikroorganisme yang meningkat sehingga mengakibatkan asam-asam humat dan ion-ion hidroksida serta fenol yang dihasilkan meningkat (Raihan, 2002). Proses pembalikan yang dilakukan secara berkala memiliki peran dalam mengurangi kemasaman kompos. 
Tabel. 5. Rata-rata $\mathrm{pH}$ pupuk organik cair kompos cacing L. rubellus

\begin{tabular}{ccccc}
\hline & \multicolumn{3}{c}{ Jenis Pakan (P) } & \\
\cline { 2 - 4 } $\begin{array}{c}\text { Bobot Koloni } \\
\text { Cacing (C) }\end{array}$ & Tanpa Pakan & $\begin{array}{c}\text { Limbah } \\
\text { Sayur Hijau }\end{array}$ & $\begin{array}{c}\text { Daun } \\
\text { Alang-alang }\end{array}$ & Rata-rata \\
\hline $50 \mathrm{~g}$ & 8,04 & 8,66 & 8,18 & 8,29 \\
$75 \mathrm{~g}$ & 8,23 & 8,72 & 8,30 & 8,44 \\
$100 \mathrm{~g}$ & 8,50 & 8,73 & 8,30 & 8,51 \\
\hline Rata-rata & $8,26^{\mathrm{a}}$ & $8,70^{\mathrm{b}}$ & $8,26^{\mathrm{a}}$ & \\
\hline
\end{tabular}

Keterangan : Angka-angka pada baris yang sama yang diikuti oleh huruf yang berbeda menunjukkan berbeda nyata menurut uji BNJ pada taraf $5 \%$.

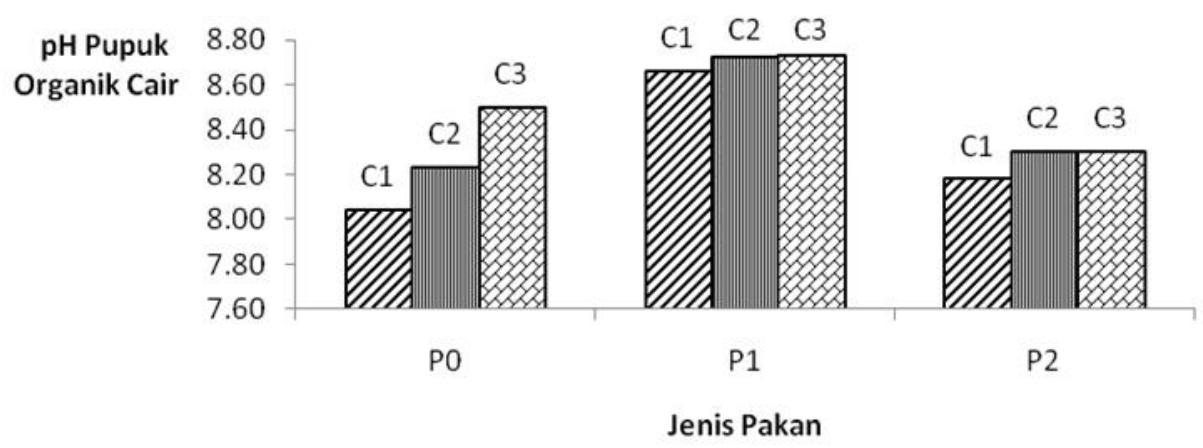

Jenis pakan : $\mathrm{P} 1=$ kontrol, $\mathrm{P} 2=$ limbah sayur hijau, $\mathrm{P} 3=$ daun alang-alang Bobot koloni : $\mathrm{C} 1=50 \mathrm{~g}, \mathrm{C} 2=100 \mathrm{~g}, \mathrm{C} 3=150 \mathrm{~g}$

Gambar 5. Pengaruh jenis pakan terhadap $\mathrm{pH}$ pupuk organik cair $(\mathrm{P}<0,05)$

Selama proses pengomposan berlangsung, asam-asam organik tersebut akan menjadi netral dan kompos menjadi matang pada kisaran pH antara 6-8 (Nurdini dkk., 2016).

\section{Suhu Pupuk Organik Cair Kompos Cacing L. rubellus}

Rata-rata suhu pupuk organik cair kompos cacing $L$. rubellus tidak berbeda nyata pada setiap perlakuan (Tabel 6). Hal ini menunjukkan semua kompos sudah matang. Perubahan suhu merupakan salah satu indikator untuk mengetahui apakah proses dekomposisi bahan organik (bahan kompos) telah berjalan dengan baik. Suhu akhir kompos telah mencapai tingkat kematangan pada semua perlakuan yang diujicobakan. Menurut Sriharti (2010) kompos dinyatakan telah matang jika suhunya telah sama dengan suhu air tanah $\left(28-30^{\circ} \mathrm{C}\right)$.

\section{KESIMPULAN}

Berdasarkan hasil penelitian ini disimpulkan bahwa :

1. Interaksi bobot koloni cacing dengan jenis pakan signifikan hanya pada kandungan unsur hara nitrogen pupuk organik cair, dimana $100 \mathrm{~g}$ bobot koloni cacing yang diberi pakan alang-alang menghasilkan unsur hara Nirogen yang paling tinggi yaitu $18,33 \mathrm{mg} \mathrm{l}^{-1}$.

2. Jenis pakan berpengaruh nyata terhadap kandungan unsur hara $\mathrm{N}, \mathrm{P}$, bobot akhir koloni cacing dan $\mathrm{pH}$ pupuk organik cair kompos cacing L. rubellus.

3. Bobot koloni cacing tidak signifikan pengaruhnya terhadap kualitas pupuk organik cair kompos cacing L. rubellus. 


\section{DAFTAR PUSTAKA}

Abbot, I. and C.A. Parker. 1981. Interactions Between Erthworms and Their Soil Environment, Soil Biol and Biochem. 191-197.

Agustina, N. 2013. Pemanfaatan Limbah Organik Kubis (Brassica oleracea) Menjadi Pupuk Cair Organik dengan Cara Fermentasi (Variabel Rasio Bahan Baku dan Lama Waktu Fermentasi). Institut Sains dan Teknologi Akprind., Yogyakarta.

Djuarnani, N., Kristian dan Setiawan. B. D, Cara Cepat Membuat Kompos. Cetakan Pertama. Agromedia Pusaka, Jakarta.

Husain, D., Sukarsono dan N. Mahmudati. 2014. Pengaruh jumlah cacing tanah (Lumbricus rubellus) dan Waktu Pengomposan terhadap Kandungan NPK Limbah Media Tanam Jamur Tiram Sebagai Bahan Ajar Biologi. Jurnal Pendidikan Biologi Indonesia. Volume 1 nomor 1.(halaman 1-8).

Lingga, P. dan Marsono, 2000. Petunjuk Penggunaan Pupuk. Penebar Swadaya, Jakarta.

Mulat, T. 2003. Membuat dan Manfaat Kascing Pupuk Organik Berkualitas. Agromedia Pustaka, Jakarta.

Munroe G. 2003. Manual of On-Farm Vermicomposting and vermiculture. Organic Agriculture Centre of Canada, Canada.

Musnamar, E. I. 2007. Pupuk Organik Cair dan Padat, Pembuatan dan Aplikasi. Penebar Swadaya, Jakarta.

Noviansyah, N.F, B.A. Kurnani dan Sudiarto. 2015. Pengaruh Perbandingan Limbah Peternakan Sapi Perah dan Limbah Kubis (Brassica oleracea) pada Vermicomposting terhadap Biomassa Cacing Tanah (Lumbricus rubellus) dan Biomassa Kascing. Jurnal Universitas Padjadjaran, Bandung.

Nurdini, L, R.D. Amanah dan A.U. Utami. 2016. Pengolahan Limbah Sayur Kol menjadi Pupuk Kompos dengan Metode Takakura. Prosiding 2005. Seminar Nasional Teknik Kimia, Yogyakarta. ISSN 1693-4393.

Pangkulun, R. 1999. Sukses Beternak Cacing Tanah Lumbricus rubellus. Penebar Swadaya, Jakarta.

Pangkulun. R. 2010. Usaha Ternak Cacing Tanah Lumbricus rubellus, Penebar Swadaya, Jakarta.

Pathma, J. and N. Sakthivel. 2012. Microbial Diversity of Vermicompost Bacteria that Exhibit Useful Agricultural Traits and Waste Management Potential. Springer Plus 1(26) : 1-19.

Raihan. 2002. Pengaruh Bahan Organik terhadap Sifat Fisik dan Kimia Tanah, serta Hasil Jagung di Lahan Lebak. Prosiding Seminar Nasional Sumber Daya Lahan. Pusat Penelitian dan Pengembangan Tanah dan Agroklimat, Bogor.

Rozaq, A. dan G. Novianto. 2010. Pemanfaatan Tanaman Enceng Gondok Sebagai Pupuk Cair. Skripsi. Jurusan Teknik Kimia Fakultas Teknologi Industri, Universitas Pembangunan Nasional "Veteran", Jawa Timur.

Saenab.A dan Y.Retnani. 2011. Beberapa Model Teknologi Pengolahan Limbah Sayuran Pasar Sebagai Pakan Alternatif pada Ternak (Kambing/Domba) di Perkotaan. Balai Pengkajian Teknologi Pertanian Jakarta. Jakarta.

Sathianarayanan, A. dan B. Khan. 2008. An Eco-Biological Approach for Resource Recycling and Pathogen (Rhizoctoniae solani Kuhn.) Suppresion. J. of Enviromental Protection Science, Vol. $2:(36-39)$.

Setiadji, B. dan Hartati. 2012. Aplikasi Pupuk Bokashi dan Pupuk Organik Cair Berbasis Azolla microphylla pada Tanaman Pakcoy (Brassica chinensis L.). Pascasarjana, Universitas Jendral Sudirman, Purwokerto. 
Sinha, R.K. 2009. Earthworms Vermicompost, A Powerful Crop Nutrien Over the Conventional Compost \& Protective Soil Conditioner Against the Destructive Chemical Fertilizers for Food Safety and Security Am-Euras. J. Agric. \& Environ. Sci., Vol 5 (1-55).

Soepardi. 1980. Sifat dan Ciri Tanah.

Fakultas Pertanian, IPB, Bogor.

Sriharti, Salim T. 2010. Pemanfaatan Sampah Taman (Rumput-rumputan) untuk Pembuatan Kompos. Prosiding Seminar Nasional Teknik Kimia "Kejuangan". ISSN 1693-4393. Balai Besar Pengembangan Teknologi Tepat Guna LIPI, Yogyakarta.
Sugiharto, D. 2006. Kecepatan Dekomposisi Sampah Organik Pasar Kota Batu serta Kandungan NPK Kompos dengan Metode Vermikompos dan EM4. Skripsi. Fakultas Keguruan dan Ilmu Pendidikan, Universitas Muhammadiyah, Malang.

Suin, N. M. 1 997. Ekologi Hewan Tanah. Bumi Aksara, Jakarta.

Wulandari, D. 2000. Pertumbuhan dan Perkembangbiakan Cacing Tanah Eisenia foetida Savigny Dalam Media Kotoran Sapi yang Mengandung Limbah Jamur Tiram. Skripsi. Jurusan Biologi, FMIPA, IPB, Bogor. 1-7. 